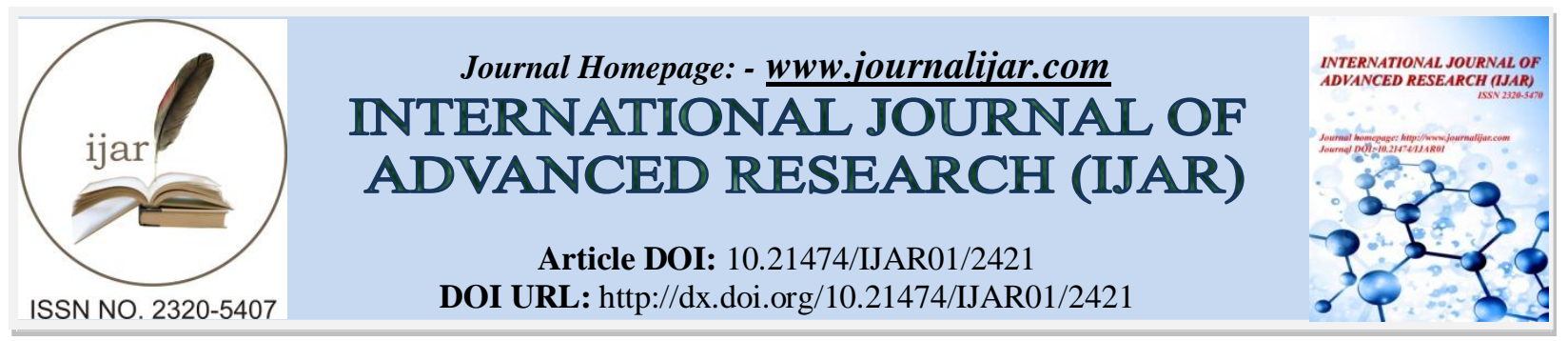

RESEARCH ARTICLE

\title{
STUDIES ON SOIL MYCOFLORA IN DIFFERENT AGRICULTURAL FIELD OF BULDHANA DISTRICT(MS).
}

\author{
Y. S. Patil and R. B. Barabde.
}

Department of microbiology, Shri. D. M. Burungale college of Science and Arts, Shegaon.444203.

\section{Manuscript Info}

Manuscript History

Received: 20 October 2016

Final Accepted: 22 November 2016

Published: December 2016

Key words:-

Fungi, Rhizosphere, agricultural field,

percent contribution and Streptomycin.

\section{Abstract}

Total of six Rhizosphere soil samples of different agricultural fields form Buldhana district were investigated for diversity of fungi. The mycoflora were isolated by using soil dilution Plate technique on Potato Dextrose agar medium supplemented with $1 \%$ Streptomycin. Identification and characterization of fungi with physicochemical parameters were done. A total of 13 species belonging to 5 genera of fungi were isolated and their percent contribution were studied.The most common among them viz; Aspergillus and Penicillium were predominant genera. Rhizopus, mucor and Trichoderma was isolated and characterized.

Copy Right, IJAR, 2016,. All rights reserved.

\section{Introduction:-}

Soil is the major component of earth's ecosystem which comprises of organic matter, minerals, gases and large numbers of macro and microorganisms. The soil ecosystem is supported by several interactions among its physical, chemical and biological components (Buscot 2005).Soils are highly complex systems, with many components playing diverse functions mainly due to the activity of soil organisms (Chiang et al., 1994). Soil microflora plays a pivotal role in evaluation of soil conditions and in stimulating plant growth (Kiran Singh et al.,1999). Microorganisms are beneficial in increasing the soil fertility and plant growth as they are involved in several biochemical transformation and mineralization activities in soils. Type of cultivation and agricultural management practice found to have greater influence on the activity of soil microflora (Mc. Gill et al., 1980). Fungi are fundamental for soil ecosystem functioning, especially in forest and agricultural soils, they play a key role in many essential processes such as organic matter decomposition and elemental release by mineralization (Christensen, 1989). The rhizosphere is the narrow region of soil that is directly influenced by root secretions and associated soil microorganisms. The rhizosphere micro-organisms predominantly help in metabolizing the root exudates. Microorganisms in the Rhizosphere complete both chemical and physical modifications to the soil profile in and around the rhizosphere that affect plants. They can be beneficial to the plant (by pathogen suppression) or detrimental (by competition for nutrients) (Sylvia et al., 2005). Fungi are an important component of the soil microbiota typically constituting more of the soil biomass than bacteria, depending on soil depth and nutrient conditions (Ainsworth and Bishy, 1995). The role of fungi in the soil is an extremely complex one and it is fundamental to the soil ecosystem. They perform ecological services that strongly impact the quality of human life and have enormous potential for providing economic benefits. Microfungi play a focal role in nutrient cycling by regulating soil biological activity (Arunachalam et al., 1997). The quantities of organic and inorganic materials present in the soil have a direct effect on the fungal population of the soil.

Corresponding Author:- Y. S. Patil.

Address:- Department of microbiology, Shri. D. M. Burungale college of Science and Arts, Shegaon.444203. 
The members and kinds of microorganisms present in soil depend on many environmental factors such as the amount and type of nutrients, moisture, aeration, $\mathrm{pH}$ and temperature etc. The aim of the present investigation is to isolate mycoflora from different agricultural fields and to observe the percentage contribution of different fungal species, by soil dilution method and soil plate method.

\section{Materials and Methods:- Collection of soil samples:-}

Rhizosphere soil samples were collected from different agricultural field of Buldhana district (S1, S2, S3, S4, S5, and S6) Table-1. In each field soil sample was collected from the surface area reaching about $10-15 \mathrm{~cm}$ depth and near the rhizosphere region of plants. Soils were collected in sterile polythene bags and sealed on the spot. Samples were stored in laboratory until further analysis.

\section{Isolation of Mycoflora:-}

Dilution plate technique described by Warcup (1955) was used for the isolation of fungi from various rhizosphere soil samples. 10 grams of soil samples were suspended in $90 \mathrm{ml}$ of distilled water. The flasks were shaken thoroughly in order to get uniform distribution of the soil particles. The soil suspensions were diluted from $10^{-2}$ to $10^{-4}$. The Volume of $10 \mathrm{ml}$ of soil sample suspension from each serial dilution was pipetted onto different melted, cooled culture media Potato Dextrose Agar (PDA) supplemented with 1\% Streptomycin. The pH of the culture media was maintained at 5.5 being optimal for the growth and sporulation in a fungi. Each culture media was prepared in distilled water and autoclaved at $120^{\circ} \mathrm{C}$ at $15 \mathrm{psi}$ for $20 \mathrm{~min}$. $1 \%$ Streptomycin was used as an antibiotic to inhibit bacterial growth. Each colony was sub cultured and maintained on potato dextrose agar slants. The inoculated plates were incubated at room temperature $28 \pm 2^{\circ} \mathrm{C}$ in an inverted position for 5-7 days.

\section{Pure Culture and identification:-}

Purification of the fungi was made by single spore culture method. A portion of the growing edge of each colony was picked up with the help of a pair of needles and mounted on a clean slide with lactophenol cotton blue. The slide was gently heated over the flame so as to remove air bubbles. The excess stain was wiped off with the help of tissue paper and then the cover slip was sealed with grease. The slide was observed under microscope. Identification of the organisms were made with the help of Manual of soil fungi (Gillman, 2001).

\section{Statistical analysis:-}

The number of colonies per plate in $1 \mathrm{~g}$ of soil was calculated. The percent contribution of each isolate was calculated by using the following formula:

$\%$ Contribution $=\quad \begin{aligned} & \text { Total No. of CFU* of an individual species } \\ & - \text { Total No. of CFU* of all species }\end{aligned}$

(*CFU-Colony forming Unit)

\section{Physicochemical analysis of soil samples:-}

The collected soil samples ware dried aseptically at laboratory for characterization of physico-chemical properties. Physical and chemical parameters of soil such as $\mathrm{pH}$, salinity, soil texture, organic carbon, nitrogen, phosphorus, potassium were analyzed. The physico-chemical parameters of the soil samples were analyzed.

\section{Results and Discussion:-}

Fungi are an important component of the soil microbiota typically constituting more of the soil biomass than bacteria, depending on soil depth and nutrient conditions. The saprophytic fungi represent the largest proportion of fungal species in soil and they perform a major role in the decomposition of plant structural polymers, such as cellulose, hemicelluloses and lignin, thus contributing to the maintenance of global carbon cycle. In the present study 112 fungal colonies of 13 fungal species were isolated from different agricultural fields of Buldhana district. The maximum fungal species belonging to Ascomycets (96 colonies) and Zygomycetes (16 colonies) were observed. Apergillus, Penicillium and Mucor species were the dominant fungal species found among the isolates. (Table-2). 
They are dependent on the nature of substrate and temporal region that favors the colonization, growth and substrate possession of the fungi (Rani et al., 2010). The soil mycoflora in different agricultural fields viz; S1, S2, S3, S4, S5 and S6, were observed. The highest contribution among them Viz; Aspergillus flavus (28.6\%), Aspergillus sydowii (33.33\%) Aspergillus niger (25\%), Penicillum citrinum (20.83\%) and Rhizopus stolanifer (19.04\%) were isolated and identified (Table-3). The frequency of mycoflora in different fields were found to be regulated by many factors like temperature, humidity, vegetation, organic and inorganic materials, soil type and texture. The fungi were mostly observed in month of June to September due to suitable temperature and humidity.(Vinay K. et al.,2015)

Table 1:- Collection of soil samples.

\begin{tabular}{|c|c|c|}
\hline Soil Sample & District & Places \\
\hline S1 & \multirow{4}{*}{ Buldhana } & Janori \\
\hline S2 & & Sangawa \\
\hline S3 & & Deulgaon mali \\
\hline S4 & & Pimpri mali \\
& & Misal wadi \\
\hline S6 & & Shelgaon \\
\hline
\end{tabular}

Table 2:- Occurrence of soil mycoflora in different agricultural field.

\begin{tabular}{|c|c|c|c|c|c|c|c|c|c|c|c|c|c|c|c|c|}
\hline \multirow[b]{3}{*}{ 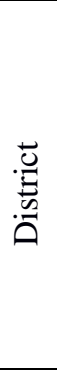 } & \multirow[b]{3}{*}{ 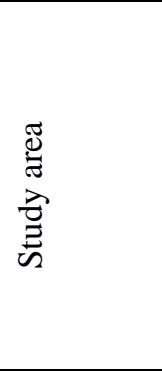 } & \multirow[b]{3}{*}{ 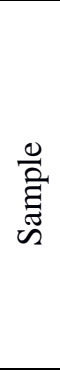 } & \multicolumn{14}{|c|}{ Average No. of Individual Colonies } \\
\hline & & & \multicolumn{7}{|c|}{ Aspergillus Species } & \multicolumn{3}{|c|}{$\begin{array}{c}\text { Penicillium } \\
\text { Species }\end{array}$} & \multirow{2}{*}{ 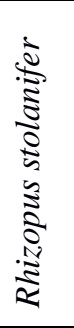 } & \multirow[b]{2}{*}{$\begin{array}{l}\dot{0} \\
\dot{0} \\
\stackrel{\Xi}{\mathbf{Z}} \\
\mathbf{Z}\end{array}$} & \multirow[b]{2}{*}{ 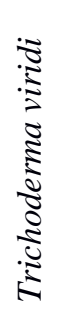 } & \multirow{2}{*}{ 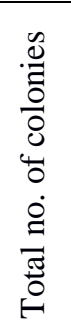 } \\
\hline & & & 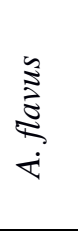 & 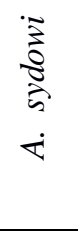 & $\begin{array}{l}\dot{\Xi} \\
\stackrel{\infty}{\vdots} \\
\dot{\pi}\end{array}$ & 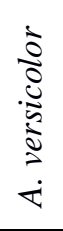 & 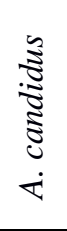 & 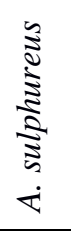 & 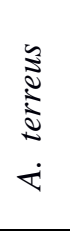 & 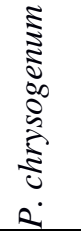 & 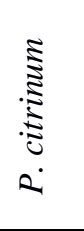 & 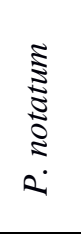 & & & & \\
\hline \multirow{6}{*}{ 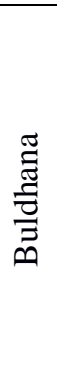 } & Janori & S1 & 2 & 5 & 5 & 1 & 1 & 1 & 1 & 2 & 5 & 1 & 2 & 2 & 2 & 30 \\
\hline & Sangawa & S2 & 2 & - & 2 & - & 1 & 1 & 1 & 3 & 5 & 1 & 3 & 2 & 3 & 24 \\
\hline & $\begin{array}{c}\text { Deulgaon } \\
\text { mali }\end{array}$ & S3 & 1 & 3 & 3 & - & - & 2 & 1 & 1 & - & - & 4 & 2 & 4 & 21 \\
\hline & $\begin{array}{c}\text { Pimpri } \\
\text { mali }\end{array}$ & $\mathrm{S} 4$ & 4 & 1 & 1 & 2 & 1 & 2 & 2 & - & - & 1 & - & - & - & 14 \\
\hline & $\begin{array}{l}\text { Misal } \\
\text { wadi }\end{array}$ & S5 & 3 & 4 & 3 & 1 & - & - & 1 & - & - & - & - & - & - & 12 \\
\hline & Shelgaon & S6 & 1 & 2 & 2 & - & 2 & 2 & 1 & - & - & 1 & - & - & - & 11 \\
\hline \multicolumn{3}{|c|}{ Total } & 13 & 15 & 16 & 4 & 5 & 8 & 7 & 6 & 10 & 4 & 9 & 6 & 9 & 112 \\
\hline \multicolumn{3}{|c|}{$\%$ contribution } & 11.6 & 13.4 & 14.3 & 3.5 & 4.5 & 7.14 & 6.25 & 5.35 & 8.92 & 3.57 & 8.03 & 5.35 & 8.03 & \\
\hline
\end{tabular}

Table 3:- Percent contribution of fungal species in different agricultural field.

\begin{tabular}{|c|l|c|c|c|c|c|c|}
\hline \multirow{2}{*}{ Sr,no. } & \multicolumn{1}{|c|}{ Fungal isolates } & \multicolumn{7}{c|}{ \% contribution } \\
\cline { 3 - 7 } & & S1 & S2 & S3 & S4 & S5 & S6 \\
\hline 1 & Aspergillus flavus & 6.7 & 8.33 & 4.8 & 28.6 & 25 & 9.1 \\
\hline 2 & Aspergillus sydowii & 16.7 & --- & 14.3 & 7.14 & 33.33 & 18.2 \\
\hline 3 & Aspergillus niger & 16.7 & 8.33 & 14.28 & 7.14 & 25 & 18.2 \\
\hline 4 & Aspergillus versicolor & 3.33 & --- & --- & 14.3 & 8.33 & --- \\
\hline 5 & Aspergillus candidus & 3.33 & 4.2 & --- & 7.14 & --- & 18.2 \\
\hline 6 & Aspergillus sulphureus & 3.33 & 4.2 & 9.52 & 14.3 & --- & 18.2 \\
\hline 7 & Aspegillus terreus & 3.33 & 4.2 & 4.8 & 14.3 & 8.33 & 9.1 \\
\hline 8 & Penicillum chrysogenum & 6.7 & 12.5 & 4.8 & --- & --- & --- \\
\hline 9 & Penicillum citrinum & 16.7 & 20.83 & --- & --- & --- & --- \\
\hline 10 & Penicillium notatum & 3.33 & 4.2 & --- & 7.14 & --- & 9.1 \\
\hline 11 & Rhizopus stolanifer & 6.7 & 12.5 & 19.04 & --- & --- & --- \\
\hline 12 & Mucor sp. & 6.7 & 8.33 & 9.52 & --- & --- & --- \\
\hline 13 & Trichoderma viridi & 6.7 & 12.5 & 19.04 & --- & --- & --- \\
\hline
\end{tabular}


Fig 1:- Percent contribution of fungal species in different agricultural field

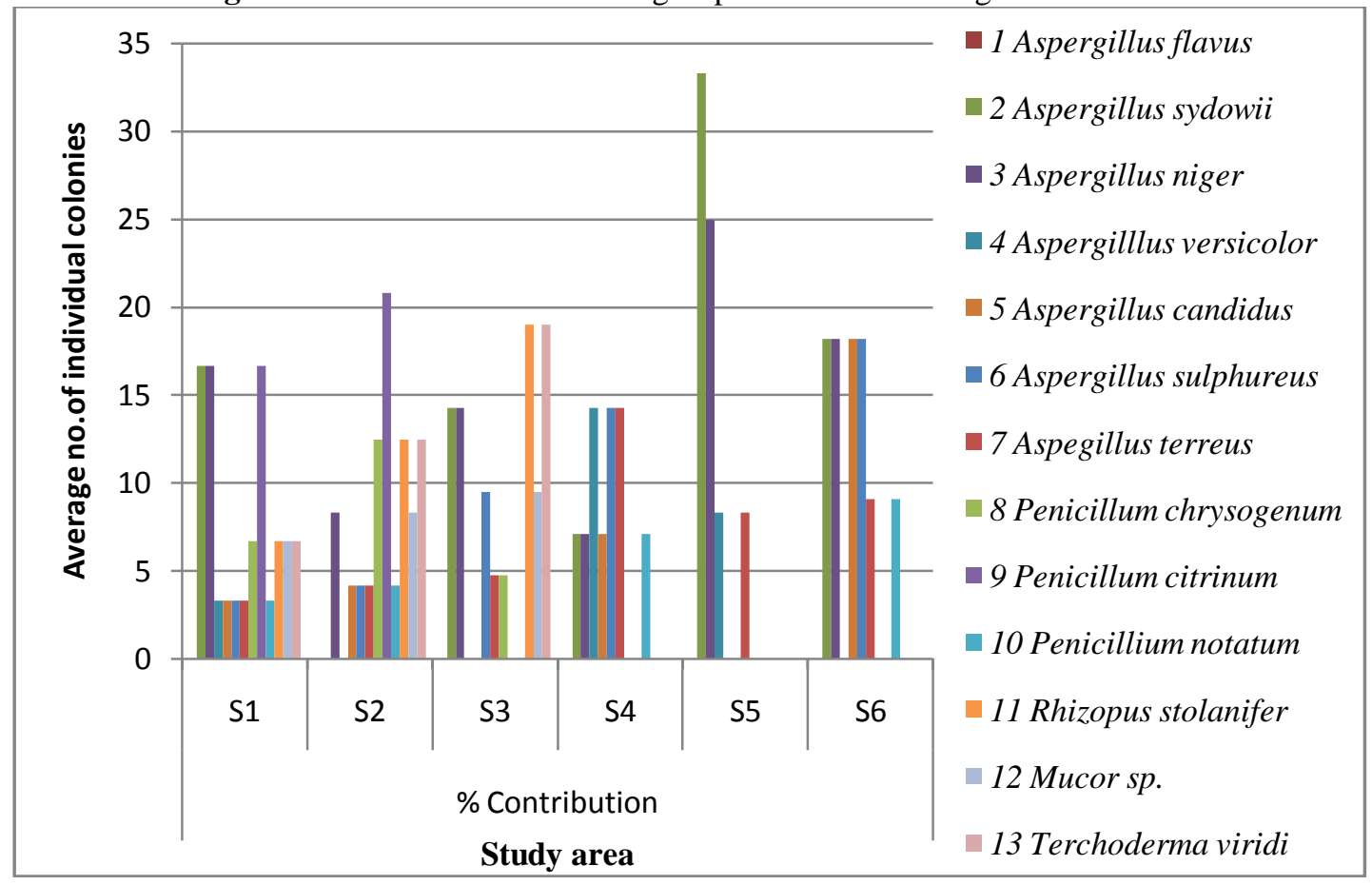

Fig 2:- Isolates of soil mycoflora in different agricultural field.

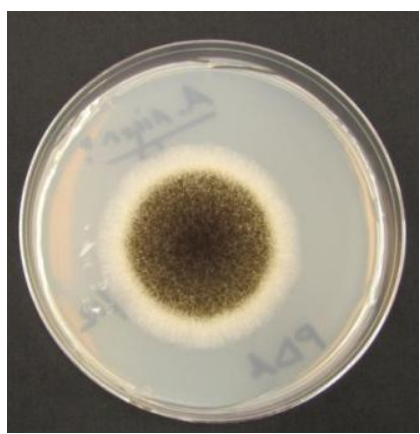

Aspergillus niger

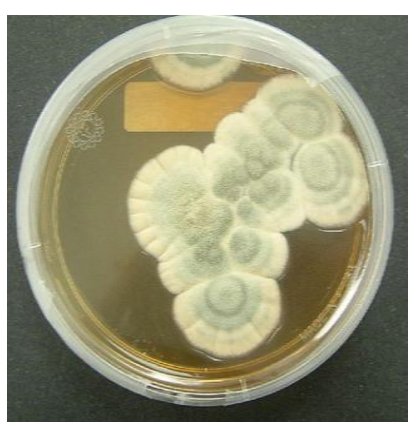

Penicillum notatum

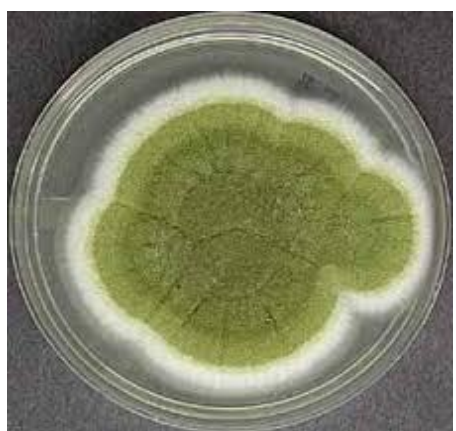

Aspergillus flavus

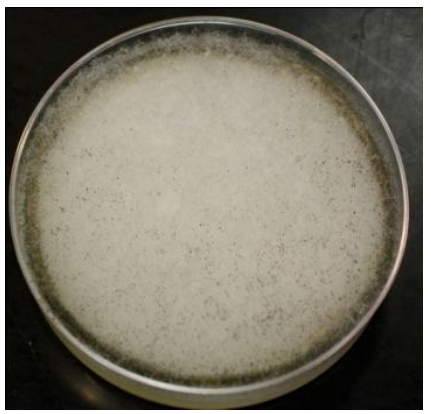

Rhizopus stolanifer

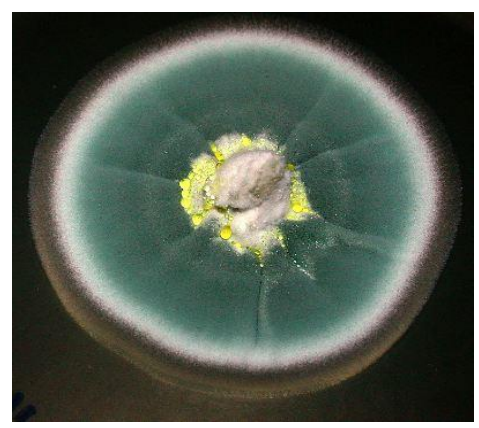

Penicillum chrysogenum

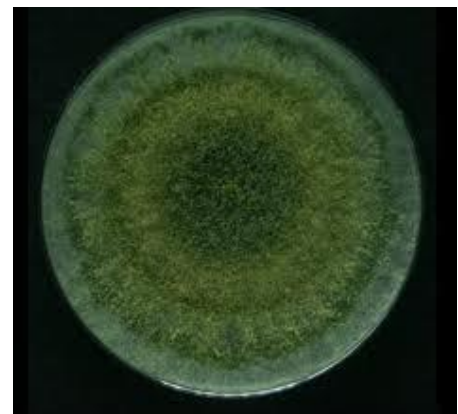

Trichoderma viridi 
Table 4:- Physicochemical parameter of soil samples from different agricultural fields.

\begin{tabular}{|c|l|c|c|c|c|c|c|}
\hline Sr.no. & \multicolumn{1}{|c|}{ Test } & \multicolumn{6}{c|}{ Soil samples } \\
\cline { 3 - 7 } & & S1 & S2 & S3 & S4 & S5 & S6 \\
\hline 1 & $\mathrm{pH}$ & 7.6 & 7.4 & 7.9 & 7.4 & 7.5 & 7.4 \\
\hline 2 & Soil salinity & 0.83 & 0.20 & 0.87 & 0.68 & 0.73 & 0.59 \\
\hline 3 & Soil colour & Grey & $\begin{array}{c}\text { Black } \\
\text { soil }\end{array}$ & Black soil & Grey & Black soil & Black soil \\
\hline 4 & Soil texture & $\begin{array}{c}\text { Sandy } \\
\text { clay }\end{array}$ & $\begin{array}{c}\text { Sandy } \\
\text { clay }\end{array}$ & $\begin{array}{c}\text { Sandy } \\
\text { clay }\end{array}$ & $\begin{array}{c}\text { Sandy } \\
\text { clay }\end{array}$ & Sandy clay & $\begin{array}{c}\text { Sandy } \\
\text { clay }\end{array}$ \\
\hline 5 & Organic carbon\% & 0.69 & 0.86 & 0.32 & 0.08 & 0.81 & 0.62 \\
\hline 6 & Nitrogen $(\mathrm{kg} / \mathrm{h})$ & 78.4 & 85.6 & 94.2 & 54.6 & 43.2 & 37.7 \\
\hline 7 & Phosphorus $(\mathrm{kg} / \mathrm{h})$ & 14.4 & 16.4 & 12.5 & 14.6 & 16.5 & 12.4 \\
\hline 8 & Pottasium $(\mathrm{kg} / \mathrm{h})$ & 334 & 423 & 255 & 136 & 225 & 347 \\
\hline
\end{tabular}

The soil $\mathrm{pH}$, organic content and water are the main factors affecting the fungal population and diversity (Zhang $e t$ al., 2001). The Organic carbon, nitrogen, phosphorus, potassium are important for fungi. In the absence of any of these the growth and sporulation of moulds as well as other microorganisms are hampered a lot. In the present study six different agricultural field soil samples of three districts were studied for screening and detected of fungal diversity. Aspergillus, Penicillium and Mucor species were dominant in all agricultural fields due to the high sporulation capacity and the Penicillium sp. were producing fungal and bacterial antibiotics and the Aspergillus $s p$. producing different kinds of toxins. These toxins may prevent the growth of other fungal species. The frequency of mycoflora in agricultural fields were found to be regulated by many factors like temperature, $\mathrm{pH}$, soil salinity, soil texture, organic carbon and inorganic materials.

\section{References:-}

1. Ainsworth, G.C, G.R. Bisby. 1995. Dictionary of the Fungi eight edition. Common Wealth Mycological Institute Kew, Surrey PP 445.

2. Arunachalam, K., Arunachalam, R.S Tripathi and Pandey. H .N, 1997. Trop. Ecol., 38: 333 - 341.

3. Buscot, F., Varma A. 2005. Microorganisms in soils: Roles in genesis and functions. Soil Biology. SpringerVerlag. Heidelberg. 3: 3-17.

4. Chiang, C.N., Soudi, B. 1994. Biologie du sol et cycles biogeochimiques. In: El Hassani TA. And Persoon E (Eds), Agronomie Moderne, Bases physiologiques et agronomiques de la production vegetale, $85-118 \mathrm{pp}$.

5. Christensen, M., A view of fungal ecology. Mycologia., 1989, 81:1-19.

6. Gilman, J.C. 2001. A Manual of Soil fungus, 2nd Indian edition, Biotech Books, Delhi.

7. Kiran Singh, Jaishree Borana, sobha Srivastava, V.A. 1999. J. Soil Biol. Ecol., 19: 11-14.

8. Mc. Gill, W.B., Cannon, K.R., Robertson, J.A., Cook, F.D. 1980. Canadian J. soil Sci., 66: 1-19.

9. Rani, C., Paneerselvam, A. 2010. Fungal diversity in the sediments of point calimere, East coast of India. $J$. Pure Appl. Microbiol., 4: 1999-2006.

10. Sylvia, D.M., Fuhrmann, J., Hartel, P., Zuberer, D.A. 2005. Principles and Applications of Soil Microbiology: Upper Saddle River, NJ, Prentice Hall, p. 408-426.

11. Vinay K, Udit Y, Ankit K. Isolation and Identification of Soil Mycoflora from Different Populated Area of Bareilly City. Bull. Env. Pharmacol. Life Sci., Vol 4 [7] June 2015: 151-156

12. Warcup, J.H. 1955. On the origin of colonies of fungi developing on soil dilution plates, Trans. Brit. Mycol. Soc., 38: 298-301.

13. Zhang, C.B., Jin, Z.X., Li, J.M. 2001. Diversity of bacterial physiological groups and microbial flora in the soil of eight forest types of Tiantai Mountain, Zhejiang, Biodiversity Sci., 9(4): 382-388. 